\title{
PReS-FINAL-2352: Apoptosis profile in patients with juvenile-onset systemic lupus erythematosus
}

\author{
B Liphaus*, MH Kiss, S Carrasco, C Goldenstein-Schainberg, \\ Faculdade de Medicina da Universidade de São Paulo, São Paulo, Brazil \\ From 20th Pediatric Rheumatology European Society (PReS) Congress \\ Ljubljana, Slovenia. 25-29 September 2013
}

\section{Introduction}

Apoptosis related proteins have been involved in immune dysregulation and development of systemic lupus erythematosus (SLE).

\section{Objectives}

To assess sFas, sFasL, sTRAIL and sBcl-2 in sera and to evaluate Fas and Bcl-2 expressions in peripheral monocytes, $\mathrm{T}$ and $\mathrm{B}$ lymphocytes from juvenile-onset SLE (JSLE) and to determine relationships with disease activity.

\section{Methods}

Forty-three JSLE patients (revised ACR criteria, mean age $=14.3 \mathrm{yrs}, 36 \mathrm{~F}: 7 \mathrm{M}$ ), and 35 age and gender matched healthy controls were studied; 30 JSLE had SLEDAI score ${ }^{3}$ 4 , reflected active disease. Soluble molecules were measured by commercial ELISA kits. Lymphocytes and monocytes were stained with specific moAbs and analyzed by flow cytometry. Kruskal-Wallis test and Spearman's rank were employed and statistical significance considered $\mathrm{p}$ value $<0.05$.

\section{Results}

JSLE sera had significantly increased sFas $(188.1 \pm 69.2$ vs $133.2 \pm 80.6, \mathrm{pg} / \mathrm{ml})$ and sTRAIL $(691.3 \pm 631.8$ vs $346.6 \pm 251.1, \mathrm{pg} / \mathrm{ml})$, decreased sFasL $(0.08 \pm 0.1 \mathrm{vs}$ $0.36 \pm 0.4, \mathrm{ng} / \mathrm{ml})$, and similar sBcl-2 $(7.4 \pm 8.6$ vs $9.3 \pm$ $9.6, \mathrm{mg} / \mathrm{ml}$ ) levels compared to healthy controls. SLEDAI score directly correlated with sFas $(\mathrm{r}=0.52 ; \mathrm{p}=$ 0.001). JSLE patients compared to controls had significantly increased Fas expression on CD3+ $(43.7 \pm 10.3 \%$ vs $28.9 \pm 9.4 \%), \mathrm{CD} 4+(20.3 \pm 6.7 \%$ vs $16.2 \pm 6.2 \%)$ and

\footnotetext{
Reumatologia, Faculdade de Medicina, Universidade de Sao Paulo, Sao
} Paulo, Brazil

C 2013 Liphaus et al.; licensee BioMed Central Ltd. This is an Open Access article distributed under the terms of the Creative Commons Attribution License (http://creativecommons.org/licenses/by/2.0), which permits unrestricted use, distribution, and reproduction in any medium, provided the original work is properly cited. The Creative Commons Public Domain Dedication waiver (http:// creativecommons.org/publicdomain/zero/1.0/) applies to the data made available in this article, unless otherwise stated.
CD8+ $(21.5 \pm 9.6 \%$ vs $12.3 \pm 5.8 \%) \mathrm{T}$ cells, and also on CD19+ B cells $(2.1 \pm 1.4 \%$ vs $1.4 \pm 0.7 \%)$, whereas, it was decreased on CD14+ monocytes $(93.6 \pm 6.9 \%$ vs $96.7 \pm 2.5 \%, \mathrm{p}=0.01)$. There was direct correlation between percentages of CD19+Fas+ cells and SLEDAI $(\mathrm{r}=0.38, \mathrm{p}=0.02)$ and inverse correlation between percentages of CD14+Fas+ cells and SLEDAI $(\mathrm{r}=-0.55, \mathrm{p}=$ 0.01 ). Mean fluorescence intensity (MFI) of Bcl-2-positive cells from JSLE patients was significantly increased in CD3+ $(28.8 \pm 8.4$ vs $22.9 \pm 4.2), \mathrm{CD} 4+(28.6 \pm 8.2$ vs $22.9 \pm 4.4)$ and $\mathrm{CD} 8+(29.4 \pm 9.4$ vs $22.8 \pm 3.6) \mathrm{T}$ cells, and also in CD19+ B cells $(25.5 \pm 9.6$ vs $21.5 \pm 3.6)$. Bcl-2 expression in CD14+ monocytes was lower in JSLE compared to controls $(25.2 \pm 18.2 \%$ vs $34.5 \pm$ $16.6 \%, \mathrm{p}=0.006)$. Direct correlation between percentages of CD19+Bcl-2+ cells and SLEDAI $(r=0.47, \mathrm{p}=$ 0.04 ) was shown.

\section{Conclusion}

JSLE patients showing high sFas and sTRAIL and low sFasL levels with Fas and Bcl-2 expressions increased on circulating $\mathrm{T}$ and $\mathrm{B}$ lymphocytes though decreased on monocytes are remarkable evidences of apoptosis role in the immune dysregulation observed. A possible role as a marker for lupus disease activity needs to be defined.

\section{Disclosure of interest}

None declared.

Published: 5 December 2013

doi:10.1186/1546-0096-11-S2-P342

Cite this article as: Liphaus et al.: PReS-FINAL-2352: Apoptosis profile in patients with juvenile-onset systemic lupus erythematosus. Pediatric
Rheumatology 2013 11(Suppl 2):P342. 